\title{
On the genus Thaumatoconcha Kornicker and Sohn (Halocyprida) with description of two new species from Southern Ocean deep sea
}

\author{
Ivana Karanovic • Simone Nunes Brandão
}

Received: 27 April 2010/Revised: 3 July 2011/Accepted: 27 July 2011/Published online: 11 August 2011

(C) Springer-Verlag and AWI 2011

\begin{abstract}
Two new Thaumatoconcha Kornicker and Sohn, 1976a species, T. dandani n. sp. and T. quasiporosa n. sp., have been described in the present paper. Both species have been collected during two expeditions to the Southern Ocean and are found in the deep sea. The first species is most closely related to $T$. caraionae Kornicker and Sohn, 1976a, but it has a very specific appearance of copulatory organ, anterior part being covered in small spines. The second species is most closely related to T. porosa Kornicker, 1985, and they differ in the carapace shape and morphology, while they have almost identical appearance of the male copulatory organ. A list of Thaumatocyprididae species and a key to the species of Thaumatoconcha are also presented in this paper.
\end{abstract}

Keywords Ostracoda - Thaumatocyprididae .

New species · Southern Ocean · Deep sea

Communicated by Peter Funch.

I. Karanovic

Department of Life Science, Hanyang University, Seoul 133-791, South Korea

I. Karanovic $(\bowtie)$

Institute of Marine and Antarctic Studies,

University of Tasmania, Private Bag 49,

Hobart, TAS 7001, Australia

e-mail: ivana.karanovic@utas.edu.au

\section{S. N. Brandão}

Zoologisches Museum und Zoologisches Institute, Universität Hamburg, Martin-Luther-King-Platz 3, 20146 Hamburg, Germany

e-mail: snbrandao@gmx.net

\section{Introduction}

Thaumatoconcha Kornicker and Sohn, 1976a (In Kornicker and Sohn 1976b the name appease as nomen nudum) is the largest genus of the family Thaumatocyprididae. It contains 10 described recent species and three species left in the open nomenclature (Kornicker and Sohn 1976a; Kornicker 1985). It is followed by Danielopolina Kornicker and Sohn, 1976a, which, so far, has 13 species. The family Thaumatocyprididae has three more genera, Thaumatomma Kornicker and Sohn, 1976a; Pokornyopsis Kozur, 1974; and Thaumatocypris Müller, 1906. Pokornyopsis and Thaumatomma are fossil genera (from Jurassic and Permian), while Thaumatocypris is a bathyal pelagic genus, with two species so far: one living southwest of Sumatra and in Indonesian area from 1,000 to $2,000 \mathrm{~m}$ (Kornicker and Sohn 1976a) and the other found in the west coast of Madagascar. Fossil genera inhabited waters not more than $200 \mathrm{~m}$ deep (Triebel 1941; Kornicker and Sohn 1976a), and majority of Danielopolina species are found in anchialine caves and blue holes (Kornicker et al. 2007). Danielopolina carolynae Kornicker and Sohn, 1976a is the only exception, and it is found at the depth of $3,459 \mathrm{~m}$ in South Atlantic (Kornicker and Sohn 1976a). All Thaumatoconcha species were mostly collected from bathyal $(2,000-3,000 \mathrm{~m})$ to abyssal $(3,000-6,000 \mathrm{~m})$ depths.

Geographical distribution of the recent Thaumatocyprididae goes from below $40^{\circ}$ north to below the Antarctic Circle (Fig. 1). Thaumatoconcha is mostly restricted to the South Atlantic and South Pacific, with exception of T. porosa Kornicker, 1985 found in Indian Ocean (Kornicker 1985) and T. polythrix found in the North Atlantic Ocean (Kornicker and Sohn 1976a). Danielopolina and Thaumatocypris, on the other hand, are found in the tropical or subtropical regions. 


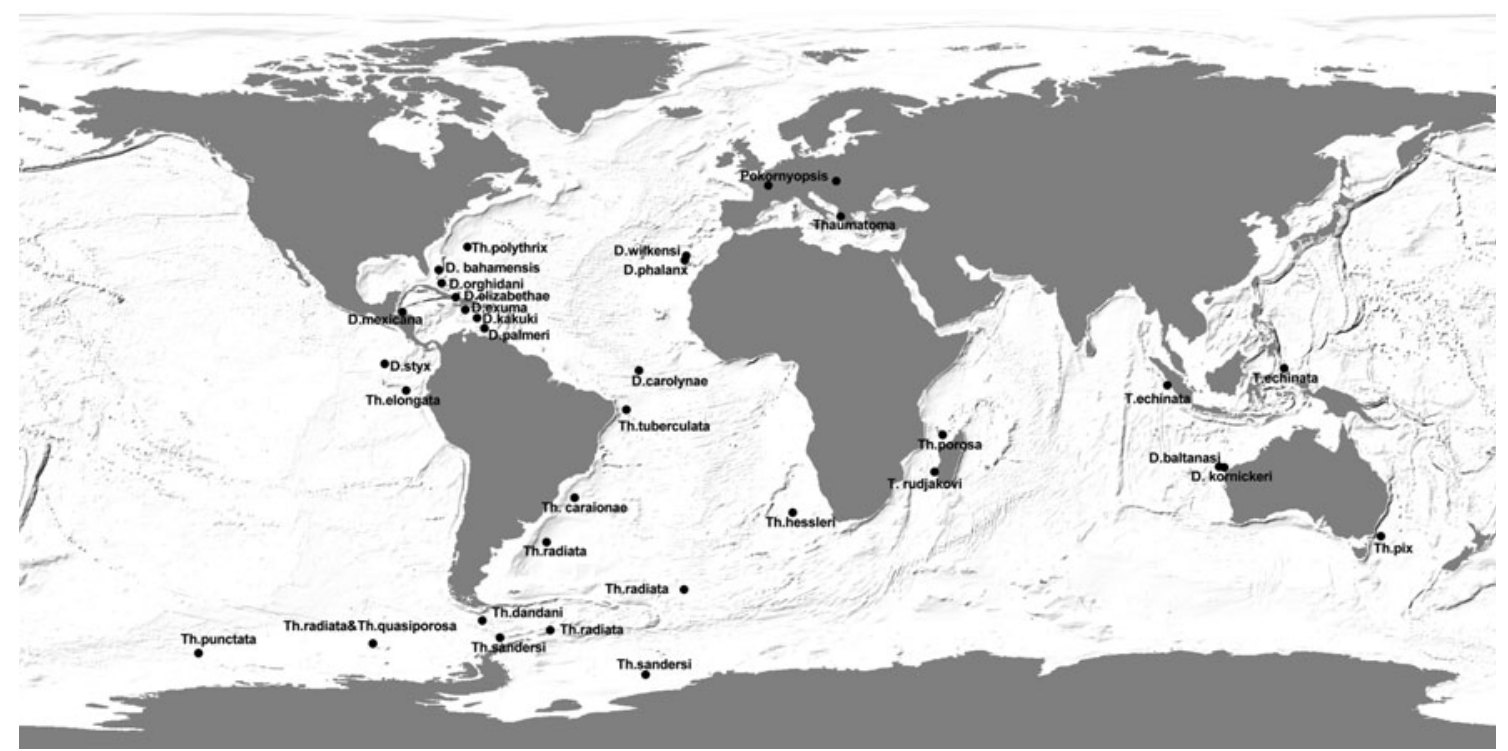

Fig. 1 Distribution of the representatives of the family Thaumatocyprididae

Morphology of Thaumatoconcha is quite conservative, and very little differences can be found in the anatomy of soft parts between species, with the exception of the male copulatory organ, which is unique for each species. Therefore, taxonomy of Thaumatoconcha is based on male characteristics and partly on the carapace shape. This is the reason why three species are still in the open nomenclature (Kornicker et al. 2007). In the present study, we describe two new species whose differential diagnosis is based on the male copulatory organ morphology and only partially on the carapace shape. On the other hand, males of Danielopolina are rare and described only for a few species. They all have very similar copulatory organ morphology. The third species dealt with in this paper is Thaumatoconcha radiata Kornicker and Sohn, 1976a. This species has the broadest distribution of all Thaumatoconcha (Fig. 1). It was recorded in different localities from $72^{\circ} 29^{\prime} \mathrm{S}$ to $36^{\circ} 05^{\prime} \mathrm{S}$ and from $27^{\circ} 41^{\prime} \mathrm{W}$ to $61^{\circ} 14^{\prime} \mathrm{W}$. It has the greatest variability in the length/height ratio in both males and females and also showing variability in the morphology of the antennula. Some additional variable morphological characters are reported here. For an easier discrimination between the species of Thaumatoconcha, a key is provided. All the species were collected during two cruises in the Southern Ocean, ANDEEP and EASIZ II. Information on these expeditions could be found in Brandt et al. (2004a) and Brandt et al. (2007a, b). Ostracods collected during these cruises have only been partially published, and they concerned Myodocopina family Cypridinidae (Chavtur et al. 2010) and different Podocopid families:
Bairdiidae (Brandão 2008a), Cytherellidae (Brandão 2008b), and Macrocyprididae (Brandão 2010). The last family is especially diverse in the Southern Ocean, more than it was predicted and so far 30 species have been reported.

\section{Materials and methods}

The samples were collected using epibenthic sledge, mesh size $500 \mu \mathrm{m}$. Specimens were fixed and stored in $96 \%$ ethanol. Detailed methods of sampling can be found in Brandt et al. (2004b). Species were dissected with the aid of Leica MS5 dissecting microscope, and soft parts were examined and drown using Leica Wetzlar microscope with a drawing tube attachment. For scanning, electron micrographs microscope LEO 1525 was used, while for microscope photographs, Zeiss MC200 was used. Drawings have been prepared with the computer program Adobe Illustrator CS and methods proposed by Coleman (2003). All material is deposited in the Zoologisches Museum, Hamburg (ZMH). Some material from the same sampling localities containing Thaumatoconcha Kornicker and Sohn, 1976a species was left undissected and will be used for further DNA sequencing.

\section{Systematic part}

Order Halocyprida Dana, 1853.

Family Thaumatocyprididae Müller, 1906. 


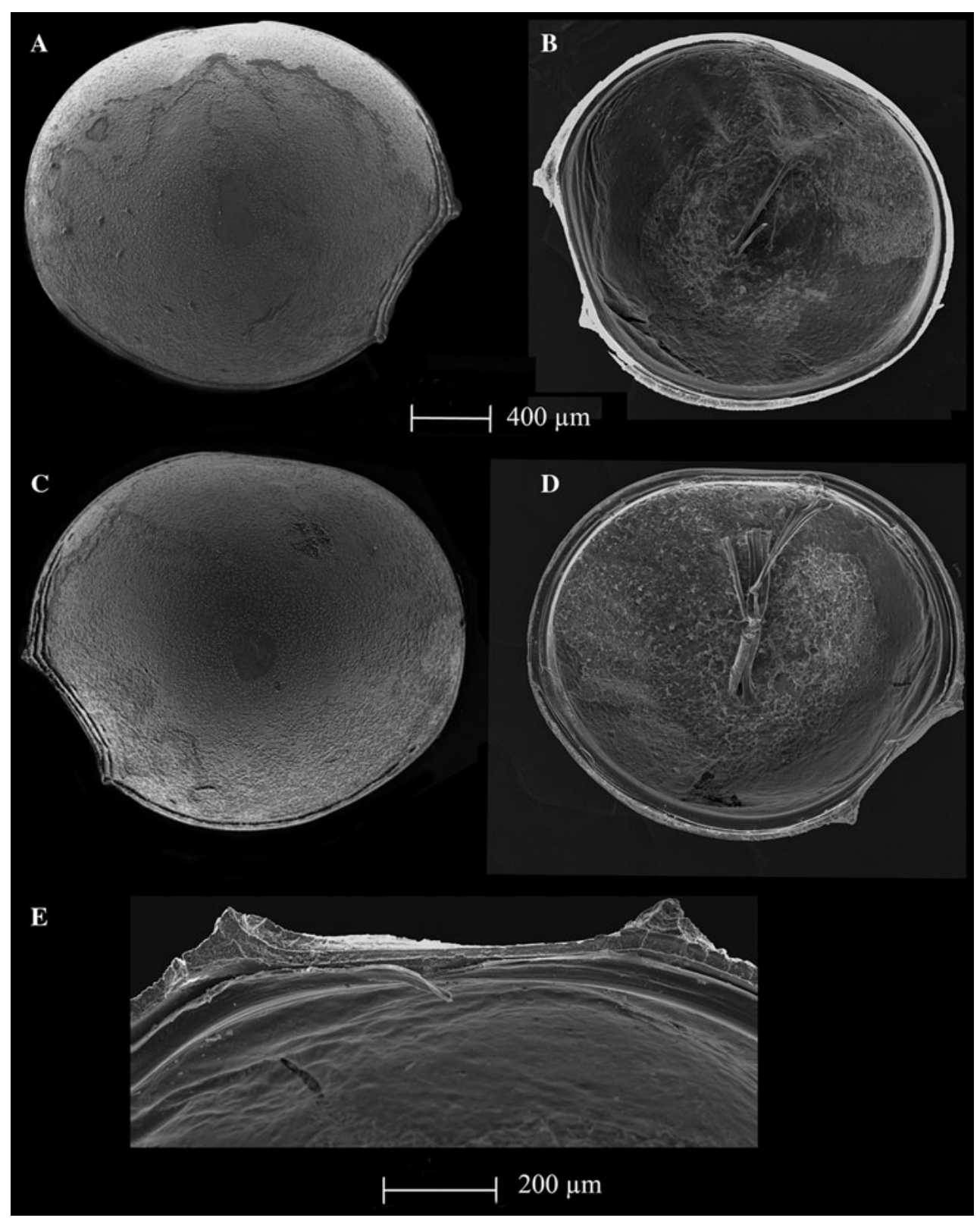

Fig. 2 Thaumatoconcha radiata Kornicker and Sohn, 1976a: a, d, e female; b, c male: a right valve, external view; b right valve, internal view; c left valve, external view; d left valve, internal view; e frontal part of left valve, internal view

Thaumatoconcha Kornicker and Sohn, 1976a.

Thaumatoconcha radiata Kornicker and Sohn, 1976a: p. 40, Figs. 3-8; 10b; 111; 12j; 18d-f; 19-23; 24a-i; 25-34 (Figs. 2, 3, 4, 5, 6, 7).

\section{Synonymy}

Thaumatoconcha radiata $\mathrm{n}$. sp. - Kornicker and Sohn, 1976a: p. 40, Figs. 3-8; 10b; 111; 12j; 18d-f; 19-23; 24a-i; $25-34$.
Thaumatoconcha radiata Kornicker and Sohn, 1976a Kornicker, 1992: Fig. 3g, h.

\section{Material examined}

1. EASIZ II, PS48/ANT XV-3, Station 114, 10/02/98, begin $74^{\circ} 36.13^{\prime} \mathrm{S} 27^{\circ} 16.13^{\prime} \mathrm{W}$, end $74^{\circ} 36.30^{\prime} \mathrm{S} 27^{\circ} 15.50^{\prime} \mathrm{W}$, depth 1,574 m: 19, $2 \hat{\jmath}$ (on slides, ZMH K42204, 42185, 42186), 3今. 2 ㅇ (on SEM stubs, ZMH K42187).

2. ANDEEP II, PS61/ANT XIX-4, Station 121, 23/03/02, begin $58^{\circ} 25.55^{\prime} \mathrm{S} \quad 25^{\circ} 0.22^{\prime} \mathrm{W}$, end $58^{\circ} 24.63^{\prime} \mathrm{S}$ 


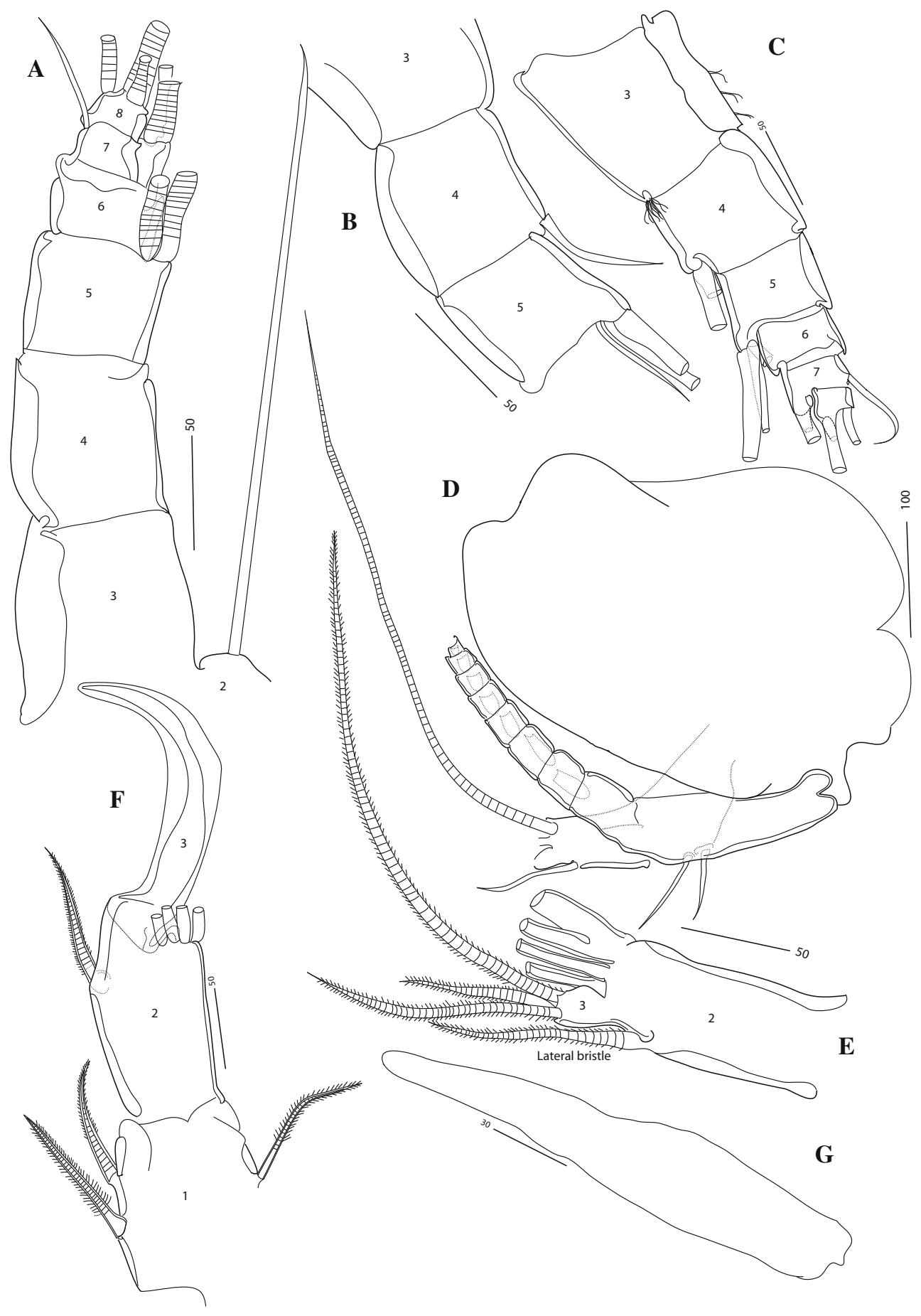

Fig. 3 Thaumatoconcha radiata Kornicker and Sohn, 1976a: a, d, e, g female; b, c, f male: a antennula, segments 3-8 (setae incomplete); b antennula segments 3-5 (detail); c antennula segments 3-8 (setae

$25^{\circ} 0.74^{\prime} \mathrm{W}$, depth $2,369 \mathrm{~m}: 1 \sigma^{\wedge}$ (on slide, $\mathrm{ZMH}$

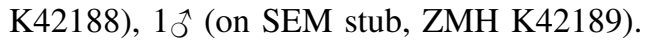

3. ANDEEP III, PS67/ANT XXII-3, Station 141, 15/03/ 05 , begin $63^{\circ} 38.29^{\prime} \mathrm{S} 50^{\circ} 37.17^{\prime} \mathrm{W}$, end $63^{\circ} 37.32^{\prime} \mathrm{S}$ $50^{\circ} 38.08^{\prime} \mathrm{W}$, depth $2,666 \mathrm{~m}$ : $1 \hat{\circ}$ (on slide, $\mathrm{ZMH}$ K42190), 10ิ (on SEM stub, ZMH K42191). incomplete); d antenna (incomplete); e endopod of antenna showing only two distal segments; $\mathbf{f}$ endopod of antenna; $\mathbf{g}$ Bellonci Organ. Scales in $\mu \mathrm{m}$

\section{Description}

Female-Left valve: $1.8 \mathrm{~mm}$ long, $1.6 \mathrm{~mm}$ high (Fig. 2d), right valve: $1.77 \mathrm{~mm}$ long, $1.5 \mathrm{~mm}$ high (Fig. 2a). Surface smooth with 3-4 anteroventral ridges and straight anteroventral margin (Fig. 2a). Valves subround. Greatest height 


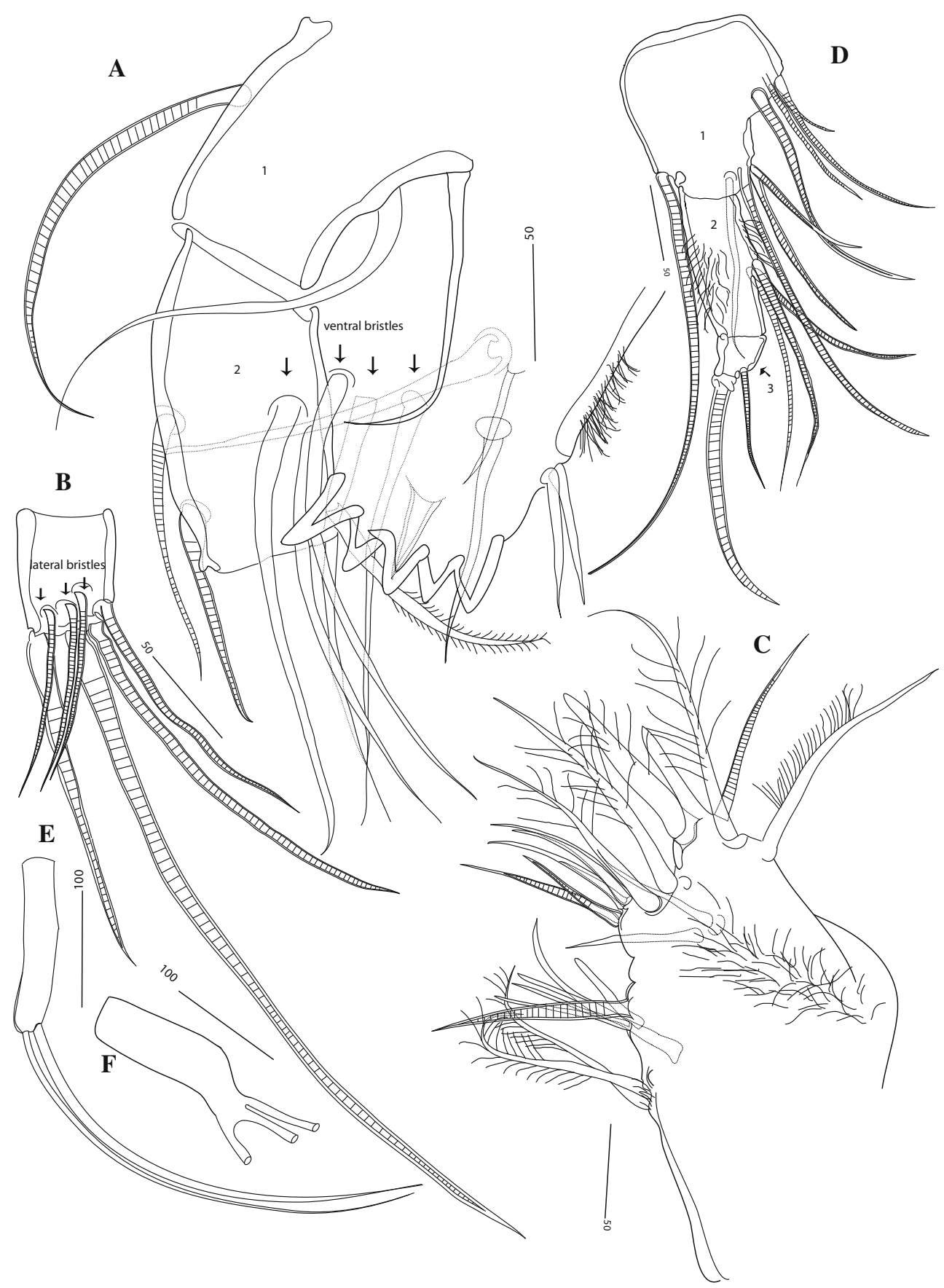

Fig. 4 Thaumatoconcha radiata Kornicker and Sohn, 1976a: a-e female; f, male: a mandible coxa and part of endopod; $\mathbf{b}$ terminal segment of mandible; $\mathbf{c}$ basis and endopod of fifth leg; $\mathbf{d}$ exopod of fifth leg; $\mathbf{e}, \mathbf{f}$ seventh leg. Scales in $\mu \mathrm{m}$

lying frontally. Anterodorsal margin broadly convex; posterior margin evenly rounded; ventral margin curving gently forward. Both upper and lower protuberances conical in shape (Fig. 2e).

Antennula (Fig. 3a): Eight-segmented, second segment with one long bristle reaching beyond the eighth segment. Dorsal margin of third segment only slightly longer than dorsal margin of fourth segment. Third and fourth segments clearly divided. Fourth segment with or without bristle, reaching beyond fifth segment. Fifth segment with $2 / 3$ bristles. Sixth segment without bristles. Seventh segment with 2 long ventral bristles and 1 short dorsal bristle (twice as long as ventral margin of seventh segment). Terminal segment with 1 short and 2 long bristles.

Second antenna (Fig. 3d, e): Exopod 9-segmented. Joints from 2 to 8 each with one long bristle, joint 9 with two long bristles. Endopod weakly 3-segmented, third segment incompletely separated from the second one. 


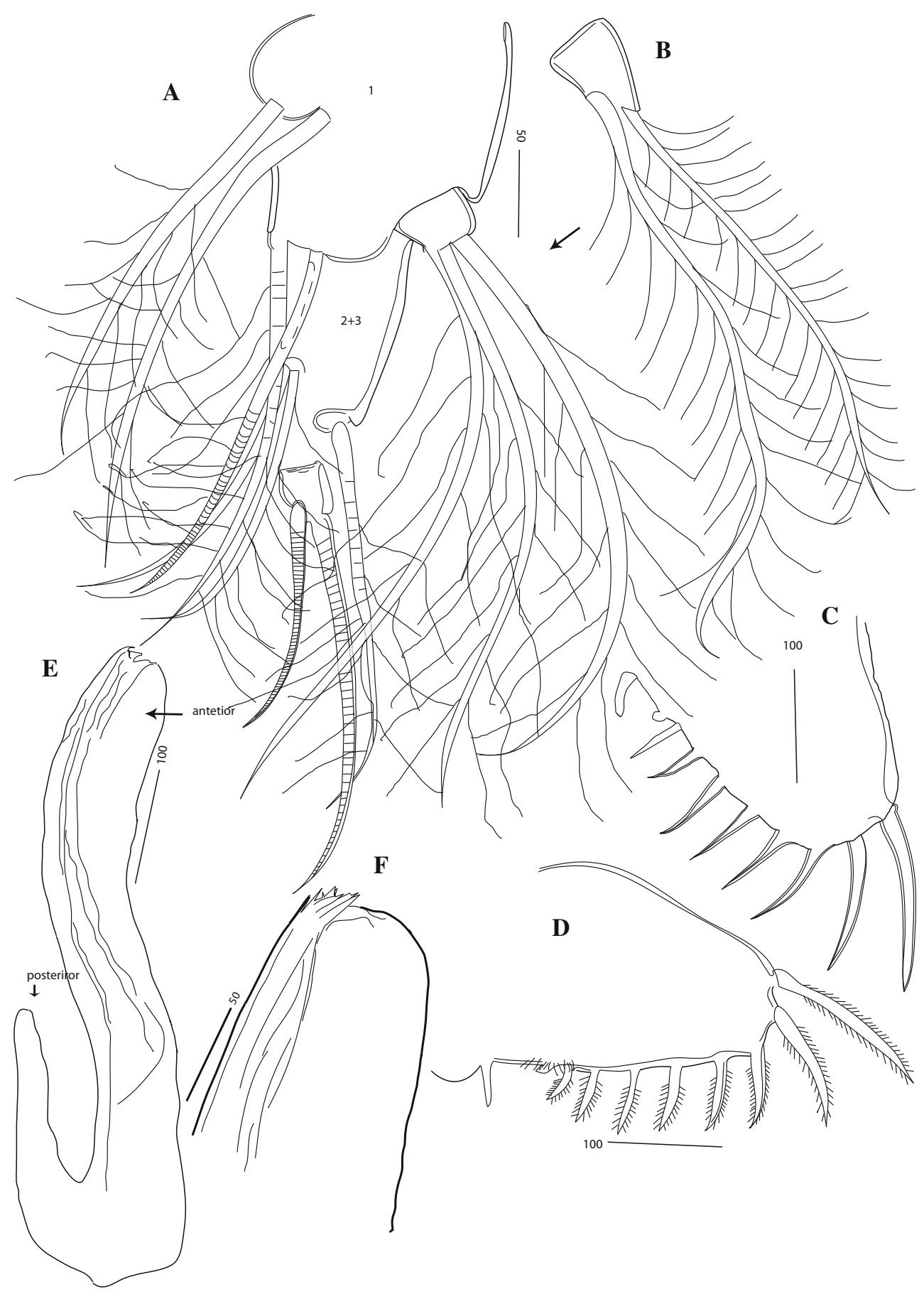

Fig. 5 Thaumatoconcha radiata Kornicker and Sohn, 1976a: a, c female; b, d-f male: a exopod sixth leg; b plate on exopod of sixth leg; c, $\mathbf{d}$ furca; e copulatory organ; $\mathbf{f}$ anterior part of copulatory organ. Scales in $\mu \mathrm{m}$

First segment with medial spine, 1 ventral and 2 dorsal bristles, both with short marginal spines; second segment narrower and longer than first, with one lateral bristle and 4 terminal bristles. Last segment with three bristles.

Mandibula (Fig. 4a, b): First segment of endopod with one seta, second with two dorsal and 4 ventral bristles: terminal segment with 3 lateral spinous bristles and 4 medial spinous bristles.
Maxilla (Fig. 7b): Endite 1 with about 10 bristles, endite 2 with 11 bristles, endite 3 with about 8 bristles. First segment of endopod with 5 or 6 slender spinous bristles on anterior margin, 2 terminal spinous bristles and 1 short subterminal bristle on ventral margin, and 1 short proximal spinous bristle. Anterior end of terminal segment with 1 claw-like bristle, distal margin with 7 slender bristles and 1 long stout posterior bristle. 


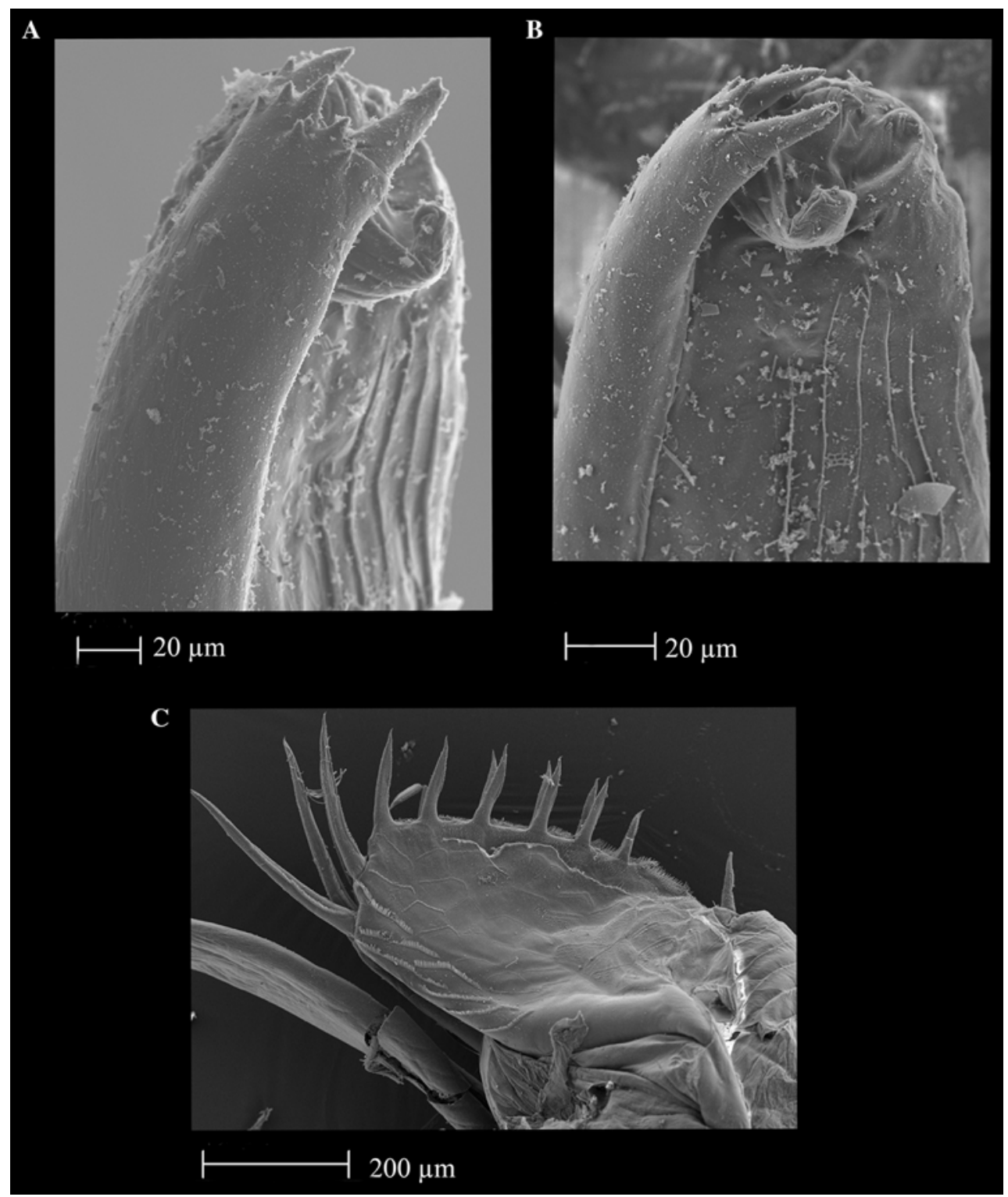

Fig. 6 Thaumatoconcha radiata Kornicker and Sohn, 1976a: Male: a, b anterior part of copulatory organ; c furca

Fifth leg (Fig. 4d): Endopod 3-segmented. First segment with one long terminal bristle near dorsal margin and 8 bristles near ventral margin, second segment hirsute and slender, with three medial bristles. End segment with one short bristle and one terminal claw.

Sixth leg (Fig. 5a): Endopod 4-segmented. First segment divided by weak suture into proximal part with 2 spinous ventral bristles and short distal part with 2 spinous bristles on ventral end of terminal margin. Small process with three plumose bristles present on dorsal corner of terminal margin of first segment. Second and third segments completely fused with one dorsal seta (positioned subterminally) and three ventral setae. Terminal segment with one bristle, which is half as long as accompanying claw.
Seventh leg (Fig. 4e): Small tapered, with two long terminal bristles.

Furca (Fig. 5c): Each lamella with two long anterior claws separated by suture from lamella, followed by 6 short claws joined to lamella; one small process, oriented posteriorly present following other claws.

Bellonci Organ (Fig. 3g): Elongate, 1-segmented, with rounded tip.

Male-Left valve (Fig. 2c): $1.8 \mathrm{~mm}$ long and $1.5 \mathrm{~mm}$ high. Right valve (Fig. 2b): $1.7 \mathrm{~mm}$ long and $1.5 \mathrm{~mm}$ high. Shape and surface characteristics same as in female.

Antennula (Fig. 3c): Eight-segmented. Similar to female, except that fifth segment carrying 3 long bristles ventrally. 
Antenna (Figs. 3f, 7a): Endopod transformed into clasping organ, which 3-segmented. Terminal segment hook-shaped with width (measured at midlength) equalling $48 \%$ of second segment width (measured just above ventral bristle).

Sixth limb: Same as in female, except that one male carrying on one leg only 2 bristles on appendage of first segment (Fig. 5b).

Seventh leg (Fig. 4e): One leg with three terminal filaments.

Furca (Figs. 5d; 6c): Similar to female except being more densely covered with spinules.

Copulatory organ (Figs. 5e, f; 6a, b; 7c, d): Consisting of two parts, anterior and posterior. Anterior part terminating in two distinctively longer teeth, and about 8 smaller ones. Posterior part terminating in a tapering process, which is carrying 3-4 smooth bristles.

All other appendages same as in female.

Remarks on variability

Thaumatoconcha radiata is a very variable species, and Kornicker and Sohn (1976a, Figs. 16, 17) have shown that
T. sandersi Kornicker and Sohn, 1976a; T. caraionae Kornicker and Sohn, 1976a and partly T. polythrix Kornicker and Sohn, 1976a, fall into length-height distribution of both adult males and females. Beside a great variability in carapace shape, the following characters are also variable: the third and fourth segments of antennula ventrally carry 0 or 1 seta, the fifth segment carries 2 or 3 setae ventrally; the third segment of the endopod of antenna carries 3, 2 or 4 bristles; the exopod of antenna can have 8 or 9 segments; the basale of mandible has 4 or 5 setae on the lateral side (see Table 13 in Kornicker and Sohn 1976a). Also, the length of the dorsal margins of the third and fourth segments of antennula is variable (Fig. 3a, c), but the dorsal margin of the third segment is not always longer than the same margin of the fourth segment, as it is reported previously for $T$. radiata (Kornicker and Sohn 1976a). The specimens collected during this study also have 0,1 or 2 setae on the ventral margin of the fourth segment of the antennula. The presence of three setae on the seventh limb (Fig. 4f) and the absence of one seta on the plate on exopod of the sixth limb (Fig. 5b) are also worth mentioning, but because this is a rare case, it should be considered as abnormality not variability. Because of
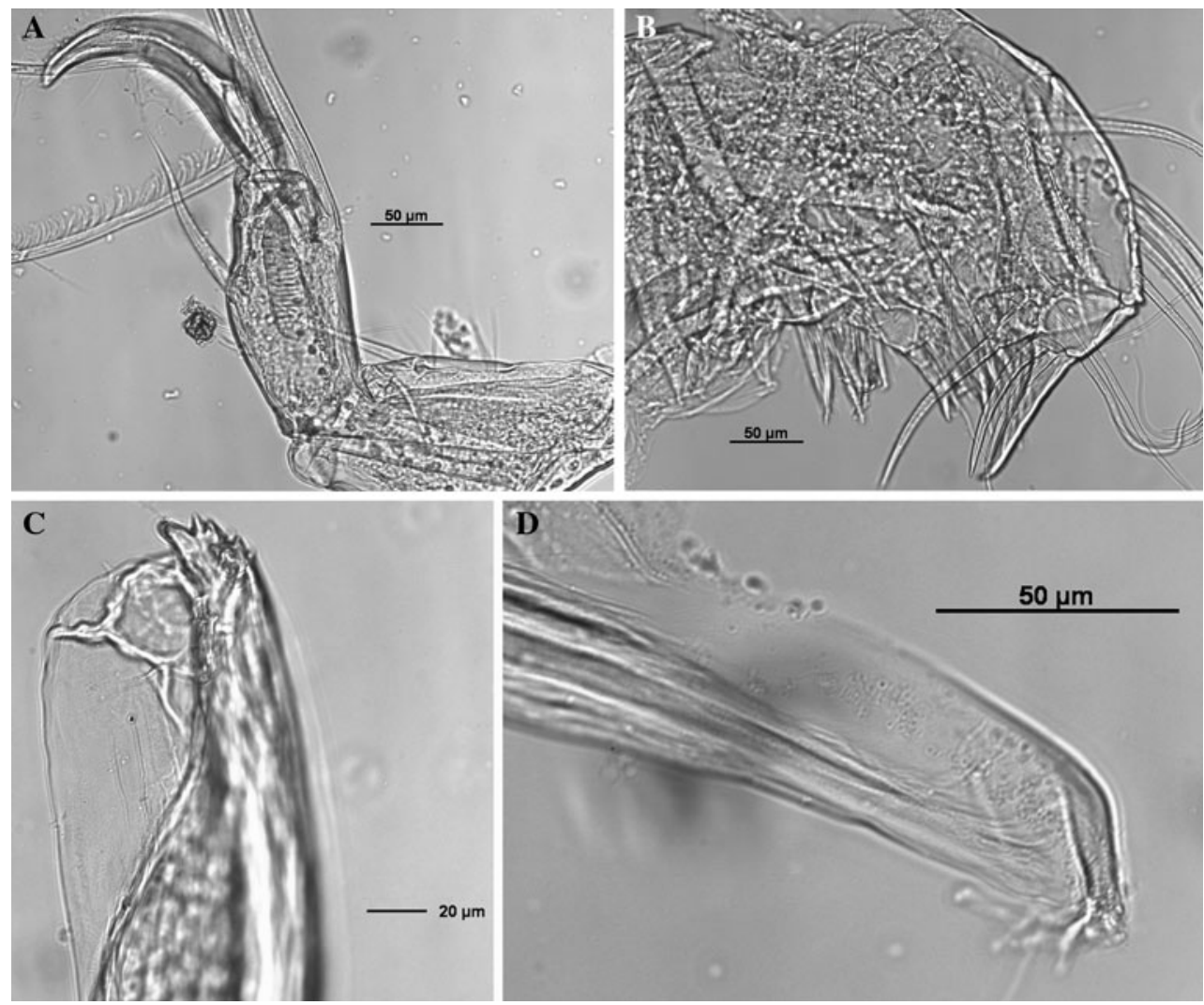

Fig. 7 Thaumatoconcha radiata Kornicker and Sohn, 1976a: a, c, d male; b female: a endopod antennae; b maxilla; c anterior part of copulatory organ; d posterior part of copulatory organ 
such drastic variability recorded in our samples, and reported previously by Kornicker and Sohn (1976a), it can be postulated that $T$. radiata is a complex of species, what can be supported by a broad distribution, unlike the other representatives of the genus. Therefore, we have left a number of specimens that are provisionally identified as $T$. radiata undissected for further DNA sequencing, what should discard or confirm our postulate of a species complex. Most recently, Kornicker et al. (2010) studied embryonic development of $T$. radiata and have shown that the most posterior appendage on the furca is not related to the claws, but it is a primitive character of the genus.

Thaumatoconcha dandani n.sp. (Figs. 8, 9, 10).

\section{Material examined}

1. (TYPE LOCALITY) ANDEEP I, PS61/ANT XIX-3, Station $41,26 / 01 / 02$, begin $59^{\circ} 21.97^{\prime} \mathrm{S} 60^{\circ} 4.27^{\prime} \mathrm{W}$ end $59^{\circ} 22.55^{\prime} \mathrm{S} 60^{\circ} 4.01^{\prime} \mathrm{W}$, depth $2,380 \mathrm{~m}$ : holotype male (soft parts on slide, valves on SEM stub, ZMH
K42192), allotype female (soft parts on slide, valves on SEM stubs, ZMH K42193).

2. ANDEEP II, PS61/ANT XIX-4, Station 140, 22/03/02, begin $58^{\circ} 15.21^{\prime} \mathrm{S} \quad 24^{\circ} 52.90^{\prime} \mathrm{W}$ end $58^{\circ} 16.29^{\prime} \mathrm{S}$ $24^{\circ} 54.10^{\prime} \mathrm{W}$, depth $2,962 \mathrm{~m}$ : 1 ㅇ (on slide, $\mathrm{ZMH}$ K42194), 1 juvenile ô (on slide, ZMH K42195).

3. ANDEEP III, PS67/ANT XIX-3, Station 94, 03/03/05, begin $66^{\circ} 39.10^{\prime} \mathrm{S} \quad 27^{\circ} 9.25^{\prime} \mathrm{W}$ end $66^{\circ} 37.16^{\prime} \mathrm{S}$ $27^{\circ} 10.14^{\prime} \mathrm{W}$, depth $4,889 \mathrm{~m}$ : 1 ô (on slide, ZMH K42196).

Diagnosis: Surface of carapace with shallow punctae and with about 10 ridges, some of which extend slightly more dorsally and ventrally. Endopod mandibule with one dorsal bristle on first segment and 2 on second. Bellonci Organ with rounded tip. Anterior process of copulatory organ with beaklike extension and with numerous thorns posterior to it.

\section{Description}

Male—Left valve: $1.9 \mathrm{~mm}$ long, $1.75 \mathrm{~mm}$ high, right valve same. Surface covered with small punctae and with

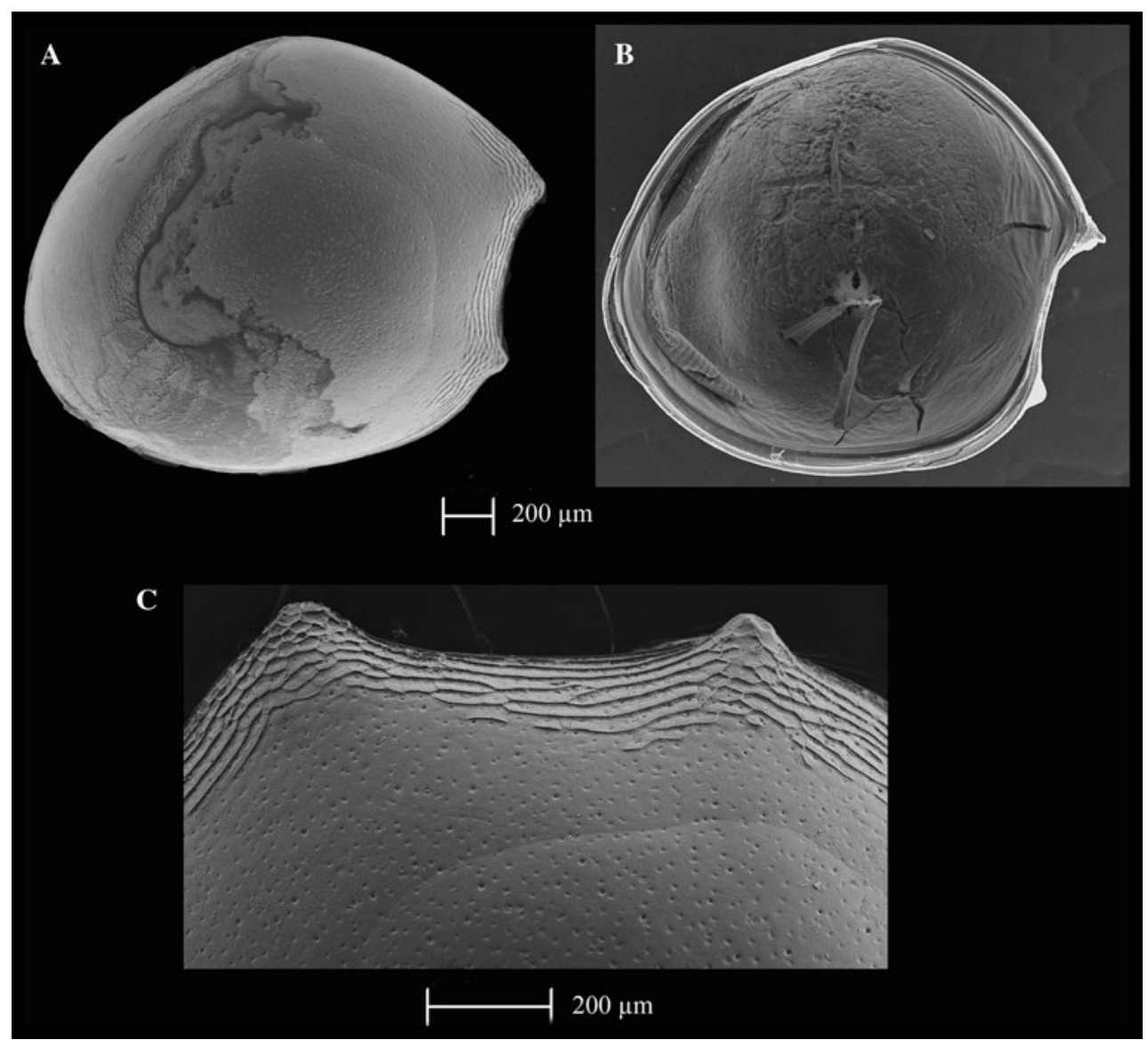

Fig. 8 Thaumatoconcha dandani $\mathrm{n} . \mathrm{sp}$. : a, c holotype (male); b allotype (female): a right valve, external view; b left valve, internal view; c anterior part of right valve, external view 
numerous anteroventral ridges, some continuous some not, and some extending slightly more dorsally and ventrally (Fig. 8c). Valves subround. Greatest height lying frontally. Anterodorsal margin broadly convex; posterior margin evenly rounded; ventral margin curving gently forward. Both upper and lower protuberances conical in shape.

Antennula: 8-segmented (Fig. 9a), second segment with one long bristle reaching beyond the eighth segment. Dorsal margin of third segment only slightly longer than dorsal margin of fourth segment. Third and fourth segments incompletely subdivided. Fourth segment with 3 long bristles. Fifth segment with 3 long setae. Sixth segment without any bristles. Seventh segment with 2 long ventral bristles and 1 short dorsal bristle (twice as long as ventral margin of seventh segment). Terminal segment with 1 short and 2 long bristles.

Second antenna: Exopod 9-segmented. Joints from 2 to 8 each with one long bristle, joint 9 with two long bristles. Endopod transformed into clasping organ (Figs 9c, 10a), which 3-segmented. Terminal segment hook-shaped with width (measured at midlength) equalling $34 \%$ of second segment width (measured just above ventral bristle).

Mandibula: First segment of endopod with one seta, second with two dorsal and 4 ventral bristles. Terminal segment with 3 lateral spinous bristles and 3 medial spinous bristles (Fig. 9e).

Maxilla: Endite 1 with about 10 bristles, endite 2 with 11 bristles, endite 3 with about 8 bristles. First segment of endopod with 5 or 6 slender spinous bristles on anterior margin, 2 terminal spinous bristles and 1 short subterminal bristle on ventral margin, and 1 short proximal spinous bristle. Anterior end of terminal segment with 1 claw-like bristle, distal margin with 7 slender bristles and 1 long stout posterior bristle.

Fifth leg: Endopod 3-segmented. First segment with one long terminal bristle near dorsal margin and 8 bristles near ventral margin, second segment hirsute and slender, with three medial bristles. End segment with one short bristle and one terminal claw.

Sixth leg: Endopod 4-segmented. First segment divided by weak suture into proximal part with 2 spinous ventral bristles, and short distal part with 2 spinous bristles on ventral end of terminal margin. Small process with three plumose bristles present on dorsal corner of terminal margin of first segment. Second and third segments completely fused with one dorsal seta (positioned subterminally) and three ventral setae. Terminal segment with one bristle, which is half as long as accompanying claw.

Seventh leg: Small tapered, with two long terminal bristles.

Furca (Fig. 9g): Each lamella with two long anterior claws separated by suture from lamella, followed by 6 short claws joined to lamella; one small process, oriented posteriorly following other claws.

Bellonci Organ (Fig. 9d): Elongate, 1-segmented, with rounded tip.

Copulatory organ (Figs. 9h, i; 10b-f): Consisting of two parts, anterior and posterior. Anterior part terminating in one beak shaped process, and distal to it, rows of spines. Posterior part terminating in a tapering process which is carrying 3 smooth bristles.

Female-Left valve (Fig. 8b): $2 \mathrm{~mm}$ long and $1.8 \mathrm{~mm}$ high. Right valve: 1.9 long and $1.8 \mathrm{~mm}$ high. Shape and surface characteristics same as in male.

Antennula: 8-segmented. Similar to male, except that fourth segment with 2 long bristles ventrally.

Antenna: Endopod (Fig. 9b) weakly 3-segmented. First segment with medial spine, 1 ventral and 2 dorsal bristles, both with short marginal spines; second segment narrower and longer than first, with one lateral bristle and 4 terminal bristles. Last segment with two bristles.

Furca (Fig. 9f): Similar to male. Two articulated claws fallen off.

All other appendages same as in male.

Etymology: The species is named after Dr. Dan L. Danielopol (combination of his first name and the first part of the last name), in honour of his contribution in understanding the family Thaumatocyprididae.

\section{Affinities}

The new species is most closely related to $T$. caraionae Kornicker and Sohn, 1976a. They share a similar carapace shape, and a similar chaetotaxy of most appendages, including 6 setae on the terminal segment of the mandible endopod. When the males are present in the sample, $T$. dandani can be easily separated from $T$. caraionae by the presence of the rows of spines on the anterior part of copulatory organ. However, in the absence of males the identification should be based on the presence of ridge-like ornamentation all the way to the dorsal hump (the point of greatest height) in $T$. caraionae. The new species can easily be separated from $T$. radiata by the carapace shape and the presence of small pits on the surface; from $T$. elongata Kornicker and Sohn, 1976a by less elongated carapace shape; from T. hessleri Kornicker and Sohn, 1976a by more conical upper and lower anteroventral carapace protrusions and by a pitted carapace; from T. polythrix Kornicker and Sohn, 1976a most easily by the presence of four setae on the dorsal margin of the first endopodal segment of mandible. Thaumatoconcha punctata Kornicker and Sohn, 1976a also has a pitted carapace surface, but the upper anteroventral protrusion of the carapace is much smaller; T. sandersi Kornicker and Sohn, 1976a has smooth 


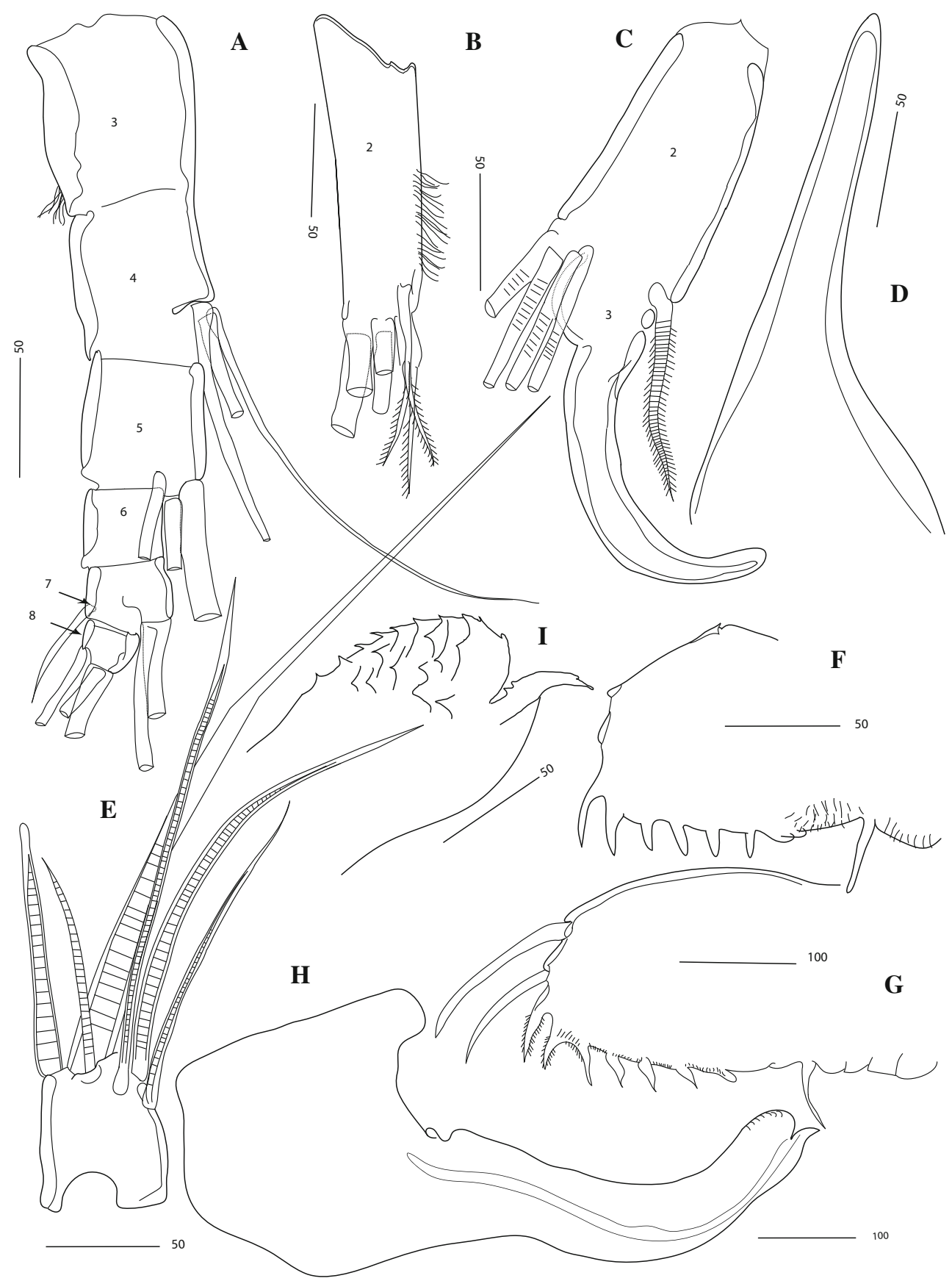

Fig. 9 Thaumatoconcha dandani n. sp.: $\mathbf{a}, \mathbf{c}, \mathbf{d}, \mathbf{e}, \mathbf{g}, \mathbf{h}, \mathbf{i}$ holotype (male); b, f allotype (female): a antennula segments from 3-8 (setae incomplete); b endopod of antenna showing only second segment; c endopod antenna, showing only second and third segments; d Bellonci Organ; e terminal segment of mandible; f, $\mathbf{g}$ furca; h copulatory organ; $\mathbf{i}$ detail of anterior part of copulatory organ. Scales in $\mu \mathrm{m}$ carapace; T. tuberculata Kornicker and Sohn, 1976a has a smooth carapace and small dorsal spines. Thaumatoconcha porosa Kornicker, 1985 differs from $T$. dandani by the carapace shape and the lack of prominent ornamentation and by the presence of a nipple on the Bellonci Organ. Thaumatoconcha pix Kornicker, 1992 also has a smooth carapace. Beside all the differences mentioned, the most prominent distinguishing feature of the new species is a characteristic appearance of the copulatory organ.

Thaumatoconcha quasiporosa n.sp. (Figs. 11, 12, 13, 14). 

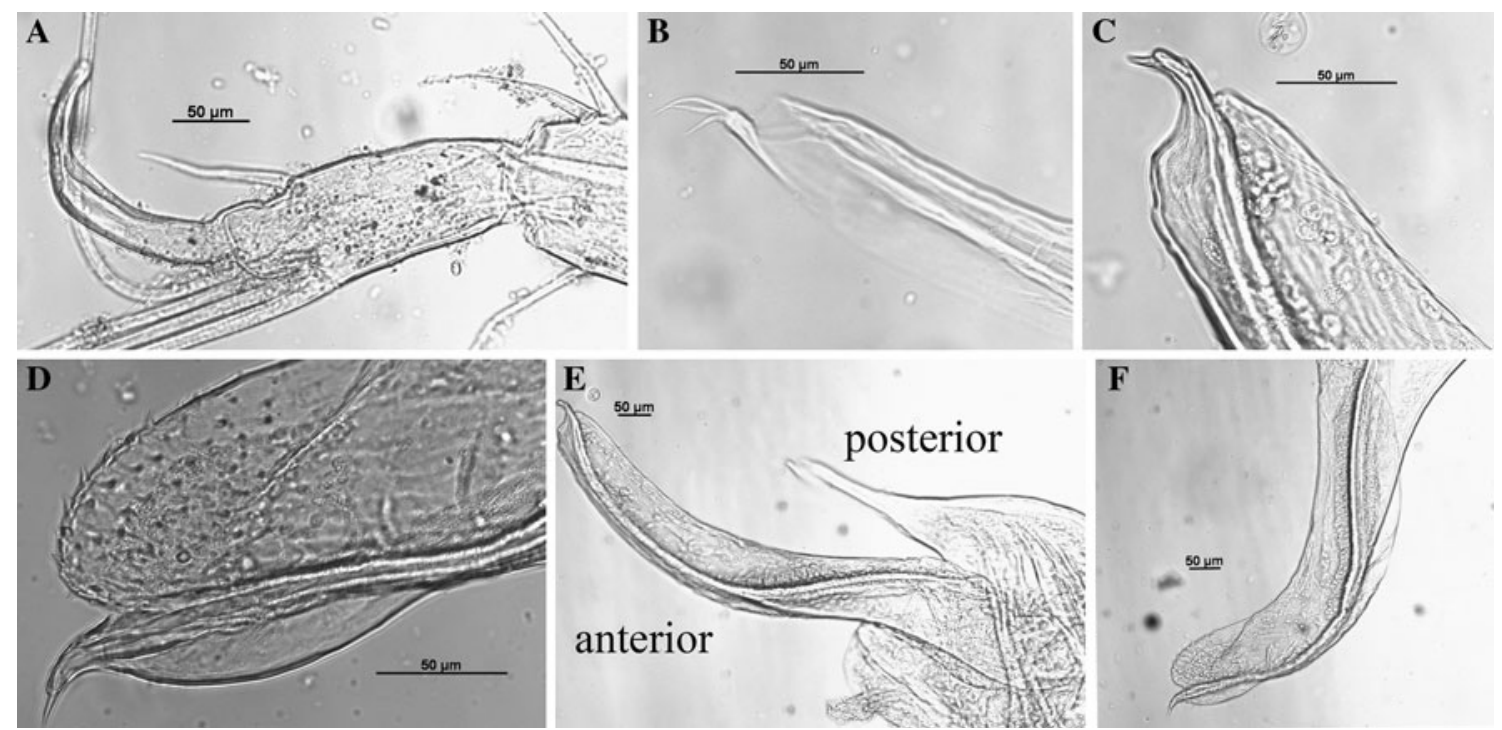

Fig. 10 Thaumatoconcha dandani n. sp.: a, b, d, e, f holotype (male); c, d, male A1: a endopod antenna; b posterior part of copulatory organ; $\mathbf{c}, \mathbf{d}$ anterior part of copulatory organ; e copulatory organ; $\mathbf{f}$ anterior part of copulatory organ

\section{Material examined}

1. (TYPE LOCALITY) EASIZ II, PS48/ANT XV-3, Station $114,10 / 02 / 98$, begin $74^{\circ} 36.13^{\prime} \mathrm{S} 27^{\circ} 16.13^{\prime} \mathrm{W}$, end $74^{\circ} 36.30^{\prime} \mathrm{S} 27^{\circ} 15.50^{\prime} \mathrm{W}$, depth $1,574 \mathrm{~m}$ : holotype $\widehat{o}$ (on slides, ZMH K42197), allotype $q$ (on slide ZMH K42198), paratype ô (on slide, ZMH K42199), 2 paratype + and 2 paratype $\hat{\sigma}$ (on SEM Stubs, ZMH K42200).

2. ANDEEP II, PS61/ANT XIX-4, Station 121, 23/03/02, begin $58^{\circ} 25.55^{\prime} \mathrm{S} \quad 25^{\circ} 0.22^{\prime} \mathrm{W}$, end $58^{\circ} 24.63^{\prime} \mathrm{S}$

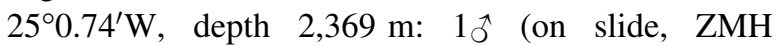
K42201).

Diagnosis: Surface of carapace with shallow punctae or smooth and with about 8 ridges, some of which extend slightly more dorsally and ventrally. Carapace in lateral view with postero-dorsal margin strongly inclined towards posterior margin. Dorsal margin highly arched. Endopod mandibule with one dorsal bristle on first segment and 2 on second. Bellonci organ with rounded tip and a terminal nipple. Anterior process of copulatory organ pointed and narrow.

\section{Description}

Male-Left valve: $1.2 \mathrm{~mm}$ long, $1.0 \mathrm{~mm}$ high (Fig. 11a), right valve (Fig. 11c): same dimension. Surface covered with small pits (Fig. 11f) with 6-8 anteroventral ridges (Fig. 11d) and straight anteroventral margin. Valves subround. Greatest height lying almost medially. Anterodorsal margin broadly convex; posterior margin evenly rounded; ventral margin curving gently forward. Both upper and lower protuberances very pointed (Fig. 11e).

Antennula (Fig. 12b): 8-segmented, second segment with one bristle dorsally and one bristle ventrally. Dorsal margin of third segment shorter than dorsal margin of fourth segment. Third and fourth segments not clearly divided. Fourth segment with 2 bristles. Fifth segment with 3 bristles. Sixth segment without bristles. Seventh segment with 2 long ventral bristles and 1 short dorsal bristle (twice as long as ventral margin of seventh segment). Terminal segment with 1 short and 2 long bristles.

Second antenna: Exopod 9-segmented. Joints from 2 to 8 each with one long bristle, joint 9 with two long bristles. Endopod transformed into clasping organ, which is 3-segmented (Figs. 12d, 14a). Terminal segment hook-shaped with width (measured at midlength) equalling 23\% of second segment width (measured just above ventral bristle, which is here positioned more medially).

Mandibula: First segment of endopod with one seta, second with two dorsal and 4 ventral bristles: terminal segment with 3 lateral spinous bristles and 3 medial spinous bristles.

Maxilla: Endite 1 with about 10 bristles, endite 2 with 11 bristles, endite 3 with about 8 bristles. First segment of endopod with 5 or 6 slender spinous bristles on anterior margin, 2 terminal spinous bristles and 1 short subterminal bristle on ventral margin, and 1 short proximal spinous bristle. Anterior end of terminal segment with 1 claw-like bristle, distal margin with 7 slender bristles and 1 long stout posterior bristle. 


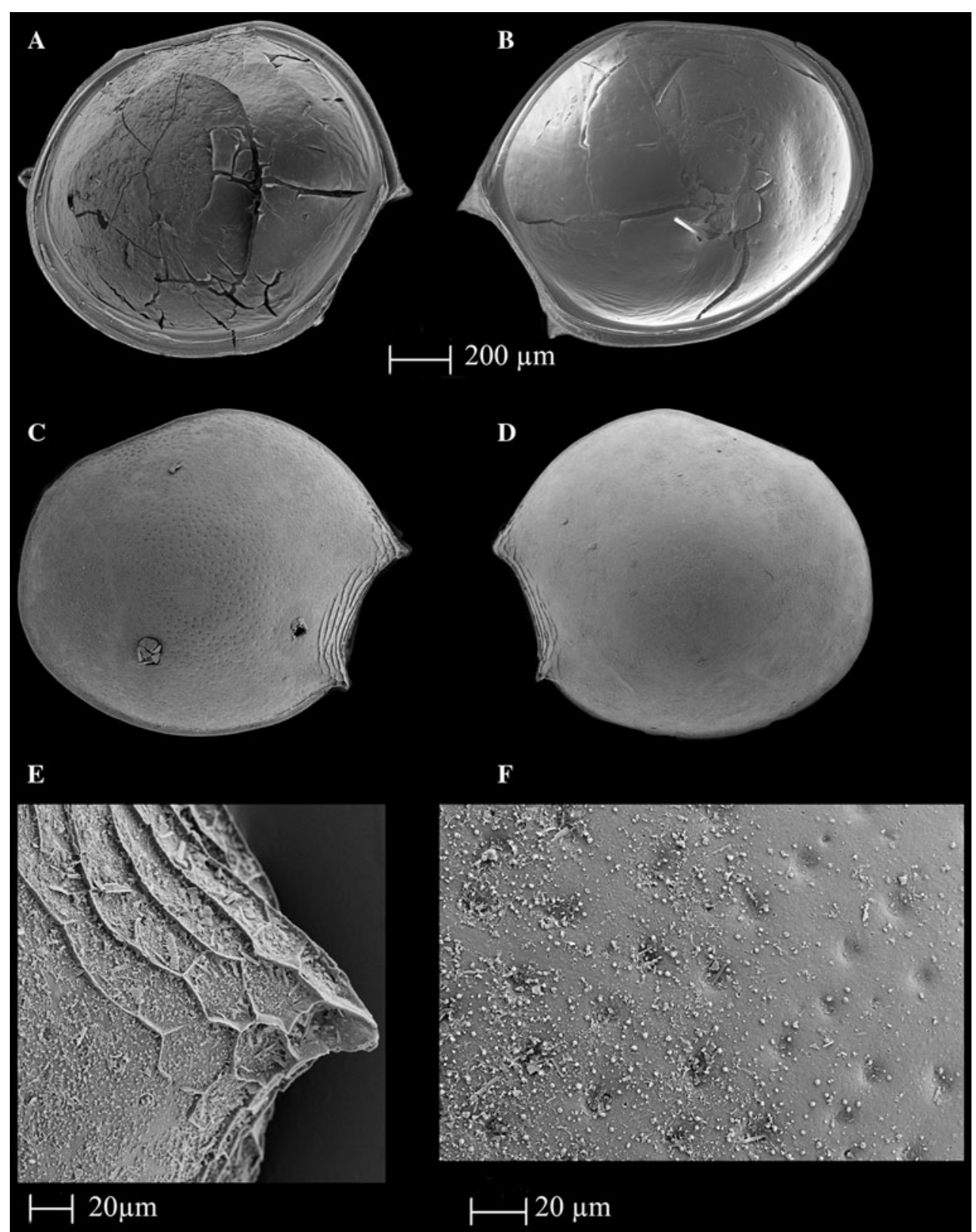

Fig. 11 Thaumatoconcha quasiporosa $\mathrm{n}$. sp.: a, c, d, e paratype (male); b, d paratype (female): a left valve, internal view; b right valve, internal view; c right valve, external view; $\mathbf{d}$ left valve, external view; e upper protuberance; $\mathbf{f}$ detail of surface ornamentation

Fifth leg (Fig. 12f): Endopod 3-segmented. First segment with one long terminal bristle near dorsal margin and 7 bristles near ventral margin, second segment with 2 medial bristles. End segment with one short bristle and one terminal claw.

Sixth leg (Fig. 13a, b): Endopod 4-segmented. First segment divided by weak suture into proximal part with 3 spinous ventral bristles, and distal part with 2 medial and one spinous bristle on ventral end of terminal margin. Small process with three plumose bristles present on dorsal corner of terminal margin of first segment. Second and third segments completely fused with one dorsal seta (positioned subterminally) and two ventral setae. Terminal segment with one bristle, which is $1 / 3$ as long as accompanying claw (Fig. 13b).

Seventh leg: Small tapered, with two long terminal bristles.

Furca (Figs. 13d, 14b): Each lamella with two long anterior claws separated by suture from lamella, followed by 6 short claws joined to lamella; one small process, oriented posteriorly present following other claws. 


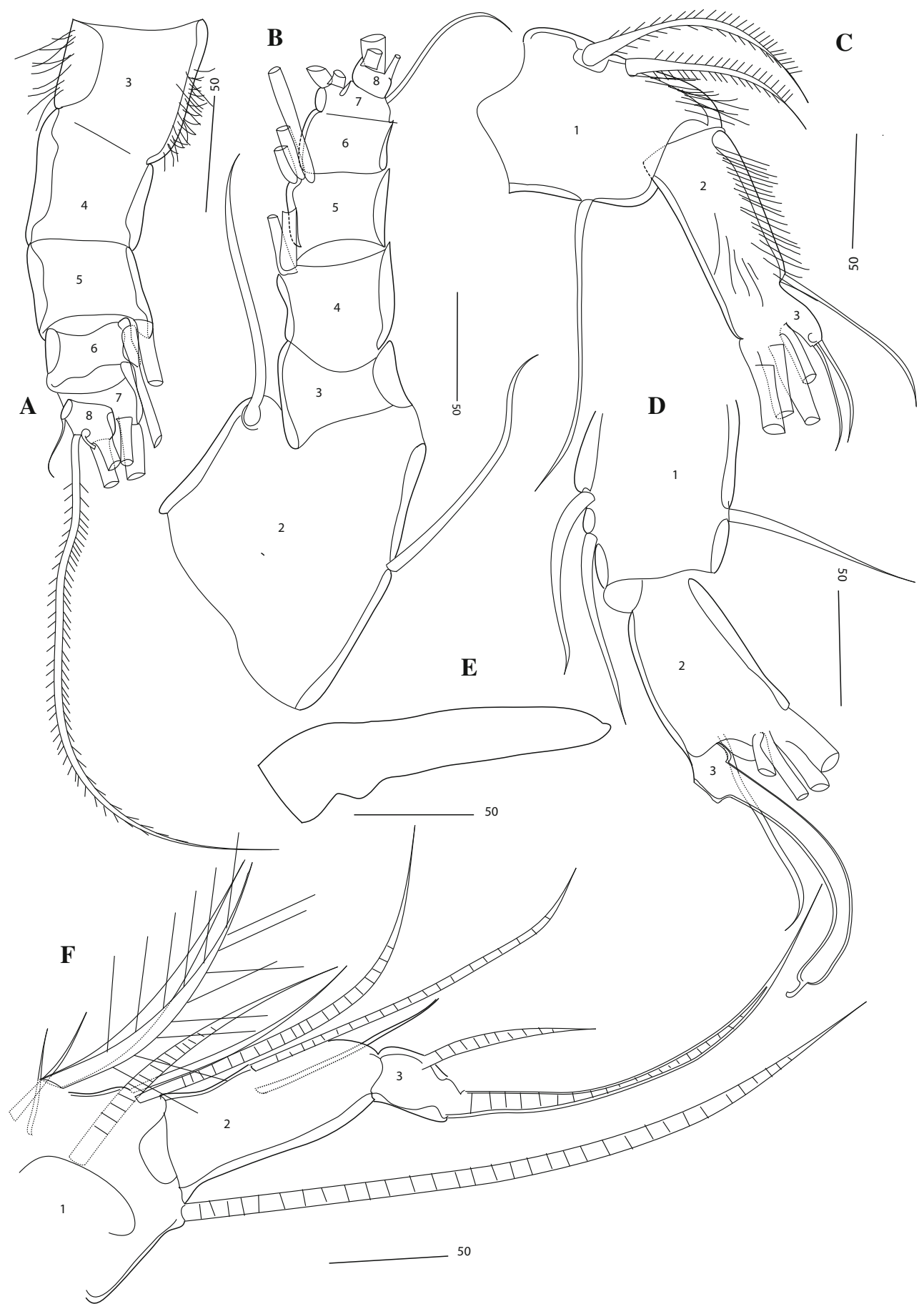

Fig. 12 Thaumatoconcha quasiporosa $\mathrm{n}$. sp.: a, c allotype (female); b, d, e, f holotype (male): a antennula, showing segments from 2 to 8 ; b antennula, showing segments from 2 to 8 , c, d endopod antenna; e rod-shaped organ; $\mathbf{f}$ fifth leg. Scales in $\mu \mathrm{m}$

Bellonci Organ (Figs. 12e, 14d): Elongate, 1-segmented, with small rounded nipple.

Copulatory organ (Figs. 13c; 14c-e): Consisting of two parts, anterior and posterior. Anterior part a single, pointed process. Posterior part terminating in a tapering process, which is carrying 3-4 smooth bristles.
Female-Shape similar to that of male (Fig. 11b, d), length varies from 1.2 to $1.4 \mathrm{~mm}$, height around $1.2 \mathrm{~mm}$, surface sometimes smooth.

Antennula (Fig. 12a): Eight-segmented. Similar to male, except that fifth segment carrying 2 long bristles ventrally, and fourth segment is without any setae. 


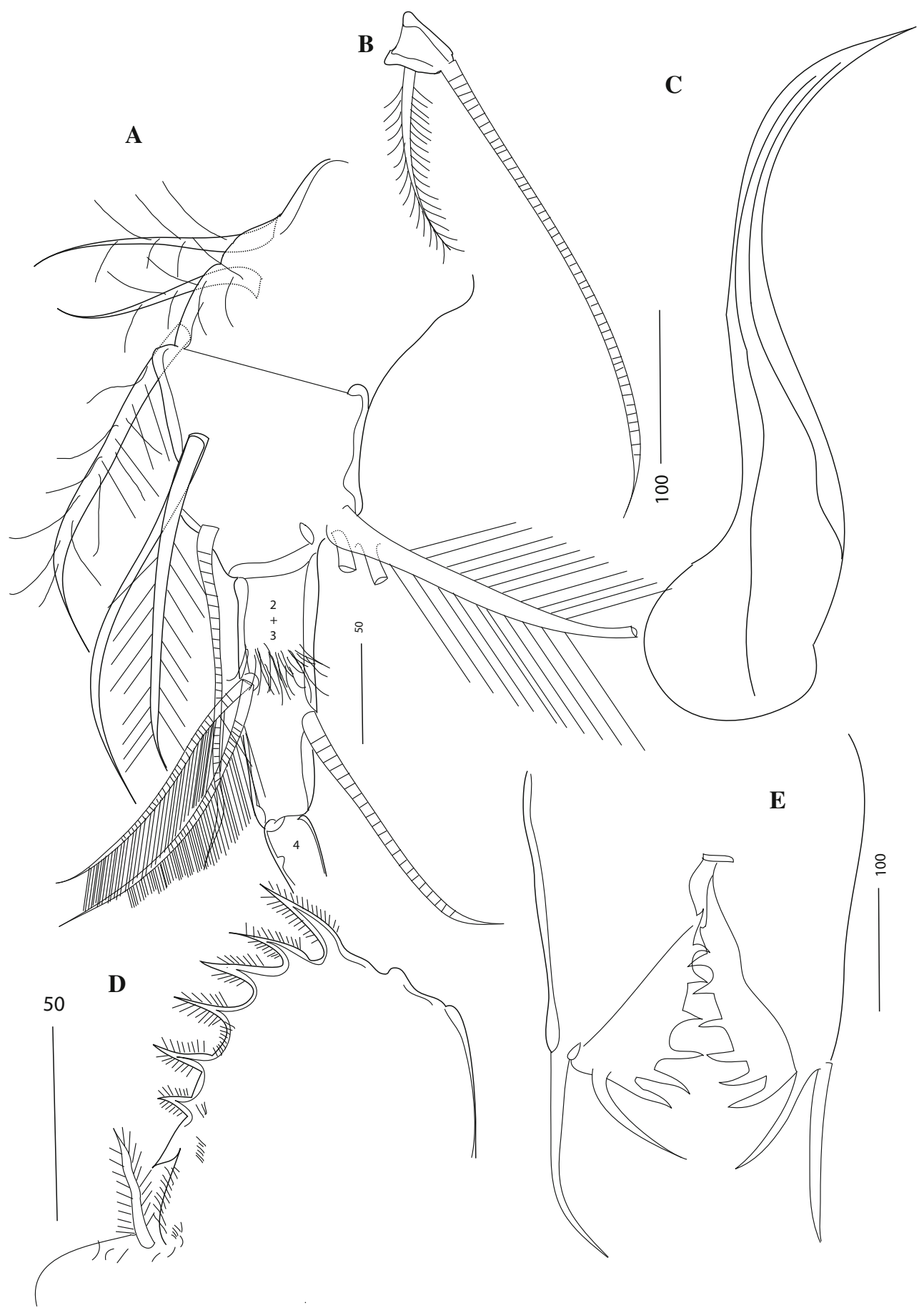

Fig. 13 Thaumatoconcha quasiporosa n. sp.: a, b, c, e holotype (male); d allotype (female): a exopod of sixth leg, b terminal segment exopod of sixth leg; c copulatory organ; d, e furca. Scales in $\mu \mathrm{m}$

Antenna: Endopod weakly 3-segmented (Fig. 12c). First segment with 1 ventral and 2 dorsal bristles; second segment narrower and longer than first, with one lateral bristle and 4 terminal bristles. Last segment with 2 bristles.

Furca (Fig. 13e): Similar to male.

All other appendages same as in male.
Etymology: The new species is named after Thaumatoconcha porosa Kornicker, 1985 because it is very similar to this species with the adding "quasi", meaning like.

\section{Affinities}

As the species name says, T. quasiporosa $\mathrm{n}$. sp. is the most closely related to $T$. porosa Kornicker, 1985 . They share 


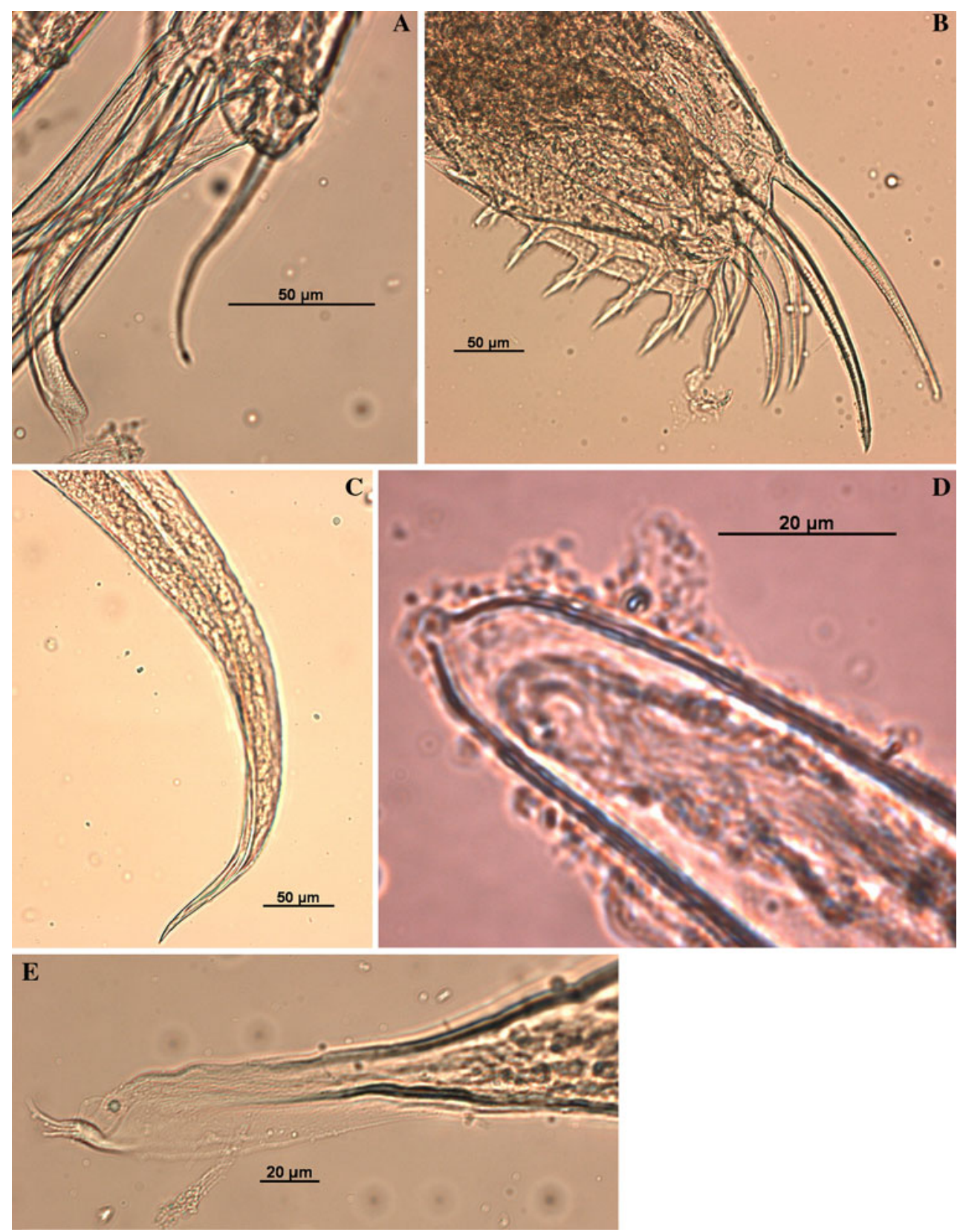

Fig. 14 Thaumatoconcha quasiporosa n. sp.: Holotype (male): a endopod antenna, b furca; $\mathbf{c}$ anterior part of copulatory organ; d tip of rodshaped organ; e posterior part of copulatory organ. Scales in $\mu \mathrm{m}$

almost identical appearance of copulatory organ. The main difference between the two species is the carapace shape, which is in the new species characterized by a steep dorsal margin, while it is rounded in T. porosa. T. porosa also has concentrated marginal pore canals in a short zone at the midlength of the ventral margin of the carapace. Beside the similar copulatory organ, two species also share a thin terminal segment of the endopod of antenna and a nipple on the tip of the Bellonci Organ. Both of them also have a very short dorsal margin of the third segment of antennula. These are the main features that also distinguish the new species from other representatives of the genus. Kornicker (1985) described $T$. porosa only after females, so it is not clear whether the females have 2 or 3 bristles on the terminal segment of the endopod of the antenna.

List of Thaumatocyprididae species with their distribution (sources of information between brackets)

Genus: Danielopolina Kornicker and Sohn, 1976a. Subgenus: Danielopolina Kornicker and Sohn, 1976a. 
1. D. (D.) carolynae Kornicker and Sohn, 1976a: South Atlantic Ocean off Brazil (Kornicker and Sohn 1976a).

2. D. (D.) kornickeri Danielopol, Baltanás and Humphreys, 2000: Christmas Island, Australia (Danielopol et al. 2000).

3. D. (D.) mexicana Kornicker and Iliffe, 1989b: Mexico (Kornicker and Iliffe 1989b).

4. D. (D.) phalanx Kornicker and Iliffe, 1995: Canary Islands (Kornicker and Iliffe 1995).

Subgenus: Humphreysella Kornicker and Danielopol, 2006.

5. D. (H.) bahamensis Kornicker and Iliffe, 1989b: Great Bahama Bank (Kornicker and Iliffe 1989b).

6. D. (H.) baltanasi Humphreys, Kornicker and Danielopol, 2009 (Humphreys et al. 2009).

7. D. (H.) elizabethae Kornicker and Iliffe, 1992: Jamaica (Kornicker and Iliffe 1992).

8. D. (H.) exuma Kornicker and Iliffe, 1998: Bahamas (Kornicker and Iliffe 1998).

9. D. (H.) kakuki Kornicker and Iliffe, 2000: Great Bahama Bank (Kornicker and Iliffe 2000).

10. D. (H.) orghidani (Danielopol, 1972): Marine Cave in Cuba (Danielopol 1972).

11. D. (H.) palmeri Kornicker, Iliffe and HarrisonNelson, 2007: Great Bahamas Bank (Kornicker et al. 2007).

12. D. (H.) styx Kornicker and Iliffe, 1989: Galapagos Island (Kornicker and Iliffe 1989a).

13. D. (H.) wilkensi Hartmann, 1985: Canary Islands (Hartmann 1985).

Genus: Thaumatoconcha Kornicker and Sohn 1976a, b.

14. T. caraionae Kornicker and Sohn, 1976a: South Atlantic Ocean off Argentina (Kornicker and Sohn 1976a).

15. T. elongata Kornicker and Sohn, 1976a: South Pacific Ocean off Peru (West edge of Peru-Chile Trench) (Kornicker and Sohn 1976a).

16. T. dandani n. sp.: Weddell Sea (present paper).

17. T. hessleri Kornicker and Sohn, 1976a: South Africa (Kornicker and Sohn 1976a).

18. T. pix Kornicker, 1992: Tasman Sea, off South SouthEast Australia (Kornicker 1992).

19. T. polythrix Kornicker and Sohn, 1976a: North Atlantic Ocean near Bermuda Islands (Kornicker and Sohn 1976a).
20. T. porosa Kornicker, 1985: Mozambique Channel, SE of Glorioso Islands (Kornicker 1985).

21. T. punctata Kornicker and Sohn, 1976a: Subantarctic Region and Antarctic Region (Kornicker and Sohn 1976a).

22. T. quasipunctata n.sp.: Subantarctic Region (present paper).

23. T. radiata Kornicker and Sohn, 1976a: South Atlantic Ocean off Argentina, Drake Passage, Weddell Sea, Scotia Sea (Kornicker and Sohn 1976a).

24. T. sandersi Kornicker and Sohn, 1976a: Drake Passage, Weddell Sea (Kornicker and Sohn 1976a).

25. T. tuberculata Kornicker and Sohn, 1976a: South Atlantic Ocean off Brazil (Kornicker and Sohn 1976a, b).

Genus: Thaumatomma Kornicker and Sohn 1976a, b.

26. T. doescheri Sohn and Kornicker, 1998: Late Permian-Greece (Sohn and Kornicker 1998).

27. T. elongata Sohn and Kornicker, 1998: Late Permian-Greece (Sohn and Kornicker 1998).

28. T. granti Sohn and Kornicker, 1998: Late PermianGreece (Sohn and Kornicker 1998).

29. T. kozuri Sohn and Kornicker, 1998: Late PermianGreece (Sohn and Kornicker 1998).

30. T. newelli Sohn and Kornicker, 1998: Late PermianGreece (Sohn and Kornicker 1998).

31. T. permiana Sohn and Kornicker, 1998: Late Permian-Greece (Sohn and Kornicker 1998).

32. T. piscifrons Kornicker and Sohn 1976a, b: Permian-Greece (Sohn and Kornicker 1998).

33. T. piscifrons Kornicker and Sohn 1976a, b: Late Permian-Greece (Sohn and Kornicker 1998).

34. T. procax Sohn and Kornicker, 1998: Late PermianGreece (Sohn and Kornicker 1998).

Genus: Thaumatocypris Müller, 1906.

35. T. echinata Müller, 1906: Indonesia (Indian Ocean) (Kornicker and Sohn 1976a, b).

36. T. rudjakovi Kornicker, 2004: West Coast of Madagascar (Indian Ocean) (Kornicker, 2004).

Genus: Pokornyopsis Kozur, 1974.

37. P. bettenstaedti (Bartenstein, 1949): Lower and Upper Jurassic_-Germany (Kornicker and Sohn 1976a, b).

38. P. feifeli (Triebel, 1941): Lower and Upper Jurassic-Germany (Kornicker and Sohn 1976a, b) and Slovakia (Aubrecht and Kozur 1995). 
Key to the genus Thaumatoconcha (amended after Kornicker and Sohn 1976a)

1. Endopod of mandibule with 4-6 dorsal bristles on first segment

T. polythrix Kornicker and Sohn, 1976a

- $\quad$ Endopod of mandibule with 1 dorsal 2 bristle

2. Both or only upper protuberance on 3 carapace poorly developed and rounded

- $\quad$ Both protuberances on carapace well 5 developed, conical in shape and sometimes very pointy

3. Carapace ornamented

- Carapace smooth

4. Third segment of female antennula distinctly longer than fourth one

- Third segment of female antennula shorter than fourth one

5. Anterior part of male copulatory organ elongate, curved, tapering to acuminate tip

- $\quad$ Anterior part of male copulatory organ different

6. Postero-dorsal margin rounded, middle of ventral margin with concentration of 25-30 pore canals

- Postero-dorsal margin strongly inclined, ventral margin without pore canals

7. Rounded part of anterior part of copulatory organ with rows of spines

- $\quad$ Rounded part smooth

T. punctata Kornicker and Sohn, 1976a

4

T. sandersi Kornicker and Sohn, 1976a

T. hessleri Kornicker and Sohn, 1976a

6

7

T. porosa Kornicker, 1985

T. quasiporosa n. sp.

T. dandani n.sp.

8

8. Tip of the anterior part of copulatory 9 organ elongate, but with more than 2 teeth

- $\quad$ Tip of the anterior part of copulatory 10 organ elongate, with maximum 2 teeth

9. Two large teeth and numerous smaller ones present

- $\quad$ Only 1 large teeth present and numerous smaller ones

10. Anterior part elongate with long tooth-like process and a minute teeth on its base

- Only a single tooth present

11. Carapace elongate

- Carapace subround

\section{Discussion}

With the description of two new species, the genus Thaumatoconcha Kornicker and Sohn 1976a, b now has 12 named species and three left in the open nomenclature. Each species can be easily identified based on the male sexual characteristics, and in the case that males are not described, based on the carapace shape and morphology. Only Thaumatoconcha hessleri Kornicker and Sohn 1976a, b has been described after females. Kornicker and Sohn $(1976 \mathrm{a}, \mathrm{b})$ noted that males are plentiful in Thaumatoconcha, unlikely in many other marine ostracod species because they die soon after mating. In general, Danielopolina Kornicker and Sohn 1976a, b species are collected in very small numbers, and males have been described for D. kornickeri Danielopol, Baltanás and Humphreys, 2000 (Kornicker et al. 2010), D. phalanx Kornicker and Iliffe, 1995; D. bahamensis Kornicker and Iliffe, 1989; D. elizabethe Kornicker and Iliffe, 1992; D. exuma Kornicker and Iliffe, 1998; and D. kakuki Kornicker and Iliffe, 2000. In all these species, only one or two male specimens have been reported, and in the last one, the description was based on a juvenile specimen (Kornicker and Iliffe 2000). Unfortunately, the type species $D$. carolynae is known only after females (Kornicker and Sohn 1976a, 1976b), but the appearance of hemipenis in known species is almost identical and very similar to Thaumatoconcha porosa Kornicker, 1985 and T. quasiporosa n. sp. The hemipenis in the Thaumatocyprididae has two lobes, a primitive character common with the family Deeveyidae Kornicker and Illife, 1985 (Kornicker et al. 2010). Males of Thaumatocypris echinata Müller, 1906 are also unknown. Carapace appearance and structure is, on the first glance, very different between Danielopolina and Thaumatoconcha, as all Danielopolina species have a dorsal spine and are much harshly ornamented. However, T. tuberculata Kornicker and Sohn 1976a, b seems to have a remnant of a dorsal spine, and carapace ornamentation may be a result of a different salinity concentration between deep ocean and anchialine caves. There can be a little argument about the validity of the genus Danielopolina, but the morphology and the cladistic analysis based on it (Baltanás and Danielopol 1995; Danielopol et al. 2000) suggest the existence of more than one lineage within the genus, a taxonomic problem partly resolved by dividing the genus into two subgenera (Kornicker et al. 2006). The new discoveries may contribute to better understanding of the phylogeny of the genus.

The water in anchialine habitats where Danielopolina species have been found varies in salinity from nearly fresh 
to fully marine. Both salinity and degree of connection to the sea control the nature of the biota (Iliffe 2000), and water currents range from negligible to low velocity (Kornicker et al. 2007). Many of the caves that are today inhabited by anchialine fauna are geologically quite young (2,000-3,000 years). It is a prevailing opinion that the present-day anchialine Thaumatocyprididae originated from ancient epigean fauna that existed in the Tethys Sea at least since the Mesozoic (Iliffe et al. 1984; Wilkens et al. 1986; Humphreys 1993; Baltanás and Danielopol 1995; Danielopol et al. 2000; Kornicker et al. 2007). This is supported mostly by the cladistic analysis of the morphological characters (Baltanás and Danielopol 1995; Danielopol et al. 2000) and by the presence of two fossil genera Pokornyopsis Kozur, 1974 and Thaumatomma Kornicker and Danielopol, 1976 in waters not deeper than $200 \mathrm{~m}$. The carapace shape of the two fossil taxa is indeed very similar to the present-day Danielopolina species, with some differences in the level of calcification and type of ornamentation (see Danielopol et al. 2000), but until now no soft body has been found preserved in the fossil record. Most recently, Siveter et al. (2010) described a myodocopid ostracods from Silurian deposits with preserved soft parts, which indicate that this species belongs to the family Cylindroleberididae, but the appearance of the carapace relate it more to the other families, especially Cypridinidae and Sarsiellidae, questioning the utility of the carapace alone in establishing the affinity of fossil ostracods. Only one Danielopolina species, D. carolynae, lives in the deep see. This species belong to the nominal subgenus, Danielopolina, which is characterized by the very primitive character such as the presence of a seta on the basal segment of the antenna. This particular seta is a novel feature for ostracods and very rare in other Crustacea (apparently present only in Mystacocarida) (Kornicker et al. 2006). Other species of this subgenus are shallow water anchialine species. Thaumatoconcha species and Humphreysella lack this seta.

The evolution of Thaumatoconcha may have started from a Danielopolina-like ancestor, which colonized deep sea waters from the shallow waters of the Tethys. It has already been postulated that the present-day eyeless oceanic Halocyprida evolved from the troglobitic Halocyprida of the family Deeveyidae (Kornicker et al. 2010). The present-day distribution of Danileopolina may be the result of the plate movement (Danielopol et al. 2000) or the oceanic dispersal (Humphreys and Danielopol 2006).

Acknowledgments We would like to thank Dr Vladimir Chavtur (Laboratory of Planktonology at the Institute of Marine Biology Far East Branch of Russian Academy of Sciences, Vladivostok) for helpful comments on the manuscript. The first author would also like to acknowledge the Alexander von Humboldt Foundation for the fellowship during which this paper was written. We also want to thank Ms Renate Walter (Zoological Museum, Hamburg) for the help with SEM.

\section{References}

Aubrecht R, Kozur H (1995) Pokornyopsis (Ostracoda) from submarine fissure fillings and cavities in the Late Jurassic of Czorsztyn Unit and the possible origin of the recent anchialine faunas. N Jb Geol Paläont Mh 196:1-17

Baltanás A, Danielopol DL (1995) Cladistic analysis of Danielopolina species (Ostracoda, Thaumatocyprididae) and the origin of the anchialine fauna. Mitt Hamb Zool Mus Inst 92:315-324

Brandão SN (2008a) New species of Bairdioidea (Crustacea, Ostracoda) from the Southern Ocean and discussions on Bairdoppilata simplex (Brady, 1880)? Bairdoppilata labiata (Müller, 1908) and Bythopussella aculeata (Müller, 1908). Zootaxa 1866:373-452

Brandão SN (2008b) First record of a living Platycopida (Crustacea, Ostracoda) from Antarctic waters and a discussion on Cytherella serratula (Brady, 1880). Zootaxa 1866:349-372

Brandão SN (2010) Macrocyprididae (Ostracoda) from the Southern Ocean: taxonomic revision, macroecological patterns, and biogeographical implications. Zool J Linn Soc 159:567-672

Brandt A, De Broyer C, Gooday AJ, Hilbig B, Thomson MRA (2004a) Introduction to ANDEEP(ANtarctic benthic DEEP-sea biodiversity: colonization history and recent community patterns) - a tribute to Howard L. Sanders. Deep-Sea Res II 51:1457-1465

Brandt A, Brökeland W, Brix S, Malyutin M (2004b) Diversity of Southern Ocean deep-sea Isopoda (Crustacea, Malacostraca)-a comparison with shelf data. Deep-Sea Res II 51:1753-1768

Brandt A, Gooday AJ, Brandão SN, Brix S, Brökeland W, Cedhagen T, Choudhury M, Cornelius N, Danis B, De Mesel I, Diaz RJ, Gillan DC, Ebbe B, Howe JA, Janussen D, Kaiser S, Linse K, Malyutina M, Pawlowski J, Raupach M, Vanreuse A (2007a) First insights into the biodiversity and biogeography of the Southern Ocean deep sea. Nature 447:307-311

Brandt A, Ebbe B, Gooday AJ (2007b) Introduction to ANDEEP, summary and outlook. Deep-See Res II 54:1645-1651

Chavtur VG, Keyser D, Bashmanov AG (2010) First record and description of male of Metavargula adinothrix Kornicker, 1975 (Ostracoda: Myodocopina) from the Southern Ocean. Zootaxa 2434:33-46

Coleman CO (2003) "Digital inking": how to make perfect drawings on computers. Organ Div Evol 14:1-14

Danielopol DL (1972) Sur la présence de Thaumatocypris orghidani $\mathrm{n}$ sp. (Ostracoda-Myodocopida) dans une grotte de Cuba. CR Acad Sci Paris 274:1390-1393

Danielopol DL, Baltanás A, Humphreys WF (2000) Danielopolina kornickeri n. sp. (Ostracoda, Thaumatocypridoidea) from western Australian anchialine cave: morphology and evolution. Zool Scripta 29:1-16

Hartmann G (1985) Danielopolina wilkensi n. sp. (Halocyprida, Thaumatocyprididae), ein neuer Ostracode aus einem marinen Lava-Tunnel auf Lanzarote (Kanarische Inseln). Mitt Hamb Zool Mus Inst 82:255-261

Humphreys WF (1993) Stygofauna in semi-arid tropical Western Australia: a tethyan connection? Mém Biospél 20:111-116

Humphreys WF, Danielopol DL (2006) Danielopolina (Ostracoda, Thaumatocyprididae) on Christmas Island, Indian Ocean, a sea mount island. Crustaceana 78:1339-1352

Humphreys WF, Kornicker LS, Danielopol DL (2009) On the origin of Danielopolina baltanasi sp. n. (Ostracoda, Thaumatocypridoidea) from three anchialine caves on Christmas Island, a seamount in the Indian Ocean. Crustaceana 82:1177-1203 
Iliffe TM (2000) Anchialine cave ecology. In: Wilkens H, Culver DC, Humphreys WF (eds) Ecosystems of the world, vol 30. Subterranean ecosystems. Elsevier, Amsterdam, pp 59-76

Iliffe TM, Hart CW Jr, Manning RB (1984) Biogeography and the caves of Bermuda. Nature 302:141-142

Kornicker LS (1985) Thaumatoconcha porosa, a new species of abyssal ostracode from the Indian Ocean (Halocyprida: Thaumatocyprididae). P Biol Soc Wash 98:1012-1021

Kornicker LS (1992) Thaumatoconcha pix, a new bathyal and abyssal species from off SE Australia (Ostracoda: Halocyprida: Thaumatocyprididae). P Biol Soc Wash 105:233-239

Kornicker LS (2004) Morphology and musculature of a new species of Thaumatocypris (Ostracoda, Halocyprida, Thaumatocypridoidea). J Crust Biol 24:54-71

Kornicker LS, Iliffe TM (1989a) Troglobitic Ostracoda (Myodocopa: Cypridinidae, Thaumatocyprididae) from anchialine pools on Santa Cruz Island, Galapagos Islands. Smithson Contrib Zool 483:38

Kornicker LS, Iliffe TM (1989b) New Ostracoda (Halocyprida: Thaumatocyprididae and Halocyprida) from anchialine caves in the Bahamas, Palau, and Mexico. Smithson Contrib Zool 470:47

Kornicker LS, Iliffe TM (1992) Ostracoda (Halocypridina, Cladocopina) from Anchialine Caves in Jamaica, West Indies. Smithson Contrib Zool 530:22

Kornicker LS, Iliffe TM (1995) Ostracoda (Halocypridina, Cladocopina) from Anchialine Caves in the Bahamas, Canary Island, and Mexico. Smithson Contrib Zool 599:93

Kornicker LS, Iliffe TM (1998) Myodocopid Ostracoda (Halocypridina, Cladocopina) from Anchialine Caves in the Bahamas, Canary Islands, and Mexico. Smithson Contrib Zool 599:93
Kornicker LS, Iliffe TM (2000) Myodocopid Ostracoda from Exuma Sound, Bahamas, and from marine caves and blues holes in the Bahamas, Bermuda, and Mexico. Smithson. Contrib Zool 606:98

Kornicker LS, Sohn IG (1976a) Phylogeny, ontogeny, and morphology of living and fossil Thaumatocypridacea (Myodocopa: Ostracoda). Smithson Contrib Zool 219:124

Kornicker LS, Sohn IG (1976b) Evolution of the entomoconchacea. Abh Verh Naturwiss Ver 18(19):55-61

Kornicker LS, Danielopol DL, Humphreys WF (2006) Description of the anchialine ostracode, Danielopolina sp. cf. D. kornickeri from Christmas Island, Indian Ocean. Crustaceana 79:77-88

Kornicker LS, Iliffe TM, Harrison-Nelson E (2007) Ostracoda (Myodocopa) from Anchaline Caves and Ocean Blue Holes. Zootaxa 1565:1-151

Kornicker LS, Humphreys WF, Danielopol DL, Harrison-Nelson E (2010) Ontogeny of an anchialine ostracod from Western Australia and comments on the origin and distribution of Halocyprididae. Crustaceana 83:715-752

Siveter DJ, Briggs DEG, Siveter DJ, Sutton MD (2010) An exceptionally preserved myodocopid ostracod from the Silurian of Herefordshire, UK. Proc R Soc Ser B 277:1539-1544

Triebel E (1941) Zur morphologie ubd Okologie der fossilen Ostracoden: mit Beschriebung einiger neuer Gattungen und Arten. Senckenbergiana 23:294-400

Wilkens H, Parzefall J, Iliffe TM (1986) Origin and age of the marine stygofauna of Lanzarote, Canary Islands. Mitt Hamb Zool Mus Inst 83:223-230 